\title{
FACTORS AFFECTING MOBILE LEARNING READINESS AMONG STUDENTS AND LECTURERS: A MODEL FOR MOBILE LEARNING READINESS IN KENYAN UNIVERSITIES
}

\author{
Stanley Mogaka Ogamba, Ikhoa Anselemo Peters \\ Department of Computer Science, Department of Information Technology \\ Masinde Muliro University of Science and Technology, P. O. Box 190-50100, Kakamega, Kenya \\ Kibabii University College, P.O. Box 1699-50200, Bungoma, Kenya
}

\begin{abstract}
Mobile learning plays an important role in developing both learning and teaching approaches in institutions of higher learning. However, a successful implementation of mobile learning strategies in Kenyan universities depends on the users' readiness to adopt and use this technology. Despite the effort by the Government of Kenya through the Ministry of Education, Science \& Technology to encourage the use of technology in improving access to knowledge and skills in learning institutions, most learners and instructors have not sufficiently embraced this innovation. The purpose of the study was to determine m-learning readiness in the Kenyan Universities and create a model for adoption by these Universities. To accomplish this purpose, the paper examines factors that affect the adoption of mobile technologies usage on mobile learning readiness among learners and instructors in Kenyan universities. A multiple regression analysis model was used to analyze the data collected from 555 participants (363 university students, 173 lecturers, and 19 heads of departments). The results of the study show that attitude, perceived ease of use, perceived usefulness, device type, m-learning content, internet availability, internet affordability, user expertise and institutional ICT strategy significantly influence the ability to use mobile devices and mobile learning readiness. The results of this research provide practitioners, educators and policy makers with meaningful insight into designing an appropriate m-learning model that supports the use of mobile-learning technology in Kenyan universities.
\end{abstract}

\section{Keywords}

Mobile learning; e-learning; learning readiness model; mobile learning technologies

\section{Academic Discipline and Sub-Disciplines}

Computer Science; Information Communication \& Technology; Computer Engineering

\section{SUBJECT CLASSIFICATION}

Computer Science Subject Classification

\section{TYPE (METHOD/APPROACH)}

Exploratory, Case Study and Survey

\section{Council for Innovative Research}

\section{Peer Review Research Publishing System}

\section{Journal: INTERNATIONAL JOURNAL OF COMPUTERS \& TECHNOLOGY}

Vol. 15 , No. 1

www.ijctonline.com, editorijctonline@gmail.com 


\subsection{INTRODUCTION}

Ease of access to learning and teaching materials is the first step to effective learning. Many researchers agree that most of the challenges facing educators, learners and policy makers revolve around the lack of readiness among technology users to use mobile technologies. Learning readiness is concerned with capturing the learners and instructors ability to access knowledge using the available learning and teaching resources. Today, there has been a significant increase in the demand for university education in Kenya. This is evident by the growing number of universities that offer open and distance learning programs through e-learning and correspondence-based programs (Medani, 2011).

The high demand for university education has been constrained by the scarce learning resources, hence mobile learning abbreviated as m-learning can help bridge this gap. Although technology has significantly contributed to the success in the education sector, Pollara \& Broussard (2011) noted that there is a slow rate at which learning institutions adopt new technologies to influence the learning behavior of students is mode of learning to integrate them is slow. One of the ways ICT can revolutionalize learning in educational institutions is through electronic learning, usually referred to as e-learning. Georgiev, Geirgieva \& Smrikarov (2004) suggests that the concept of m-learning should involve the learning experience of anywhere, anytime and not always using cables to connect.

Learners who are introverts and do not like to raise hands to answer questions or give comments can find mobile learning useful in asking questions or taking part in collaborative problem solving. Students therefore do not need to go physically to a college. The government of Kenya permitted establishment of a national open university in 2008 that is expected to use ICT and internet to conduct programs (Ratemo, 2012).

Mobile phones have been considered tools of communication only however, besides communication these devices can offer a wide range of useful services. Habitzel (2006) observes that students can acquire knowledge move effectively if content is broken down into smaller and simpler units that can be understood. This suggests that mobile learning is the best medium because it supports this kind of learning through SMS (short message service), pre-recorded MP3 files, etc. With the rapid change of technology mobile phones have been developed with advanced features that enable them offer many services besides communication.

A majority of university students are using wireless devices such as notebook PCs, personal digital assistants and smart phones. However, there is a need for a strategy to ensure effectively use these devices to support mobile learning. The ever-changing world of technology necessitates a paradigm shift in the education sector to allow for optimal utilization of emerging technologies to improve learners' acceptance and use rates (Salim, 2013).

Students of the $21^{\text {st }}$ century are more technology savvy than their older siblings, hence they expect their learning needs to be met anywhere, anytime and with help of hand-held devices. Developing countries in Africa are increasingly discovering the potential of information and communication technology in enhancing educational opportunities. Mobile devices and ICT applications are seen as potential tools in enabling access to educational materials and better quality of education.

Kenyan government has developed e-learning strategies and it is rapidly expanding ICT use in educational institutions. Mlearning programs have not been considered despite the increased rate of mobile usage among students of higher learning institutions. In fact, it is illegal for high school students to own mobile phones in Kenyan secondary schools. There is a need to formulate a policy that can change the perception on use of mobile learning devices by educators and stakeholders in the education sector.

Successful implementation of m-learning programs involves careful planning. Before implementation of $\mathrm{m}$-learning programs, infrastructure must be established, ICT services expanded, development of curriculum and content (Ratemo, 2012). In their research, Ogechi \& Bosire-Ogechi (2011) observed that the current technological changes and the rapid advancement in ICT have a positive impact on many lives. However, many aspects of this technology are developed in developed countries and are therefore not suited to the needs of the developing countries. There is the need to re-think about how technology can be used to meet the needs of learners and lecturers in universities in developing countries.

The 2013 e-readiness survey considered use of smartphones in learning. About $53 \%$ of students reported owning smartphones and only $24.1 \%$ of them had very good or excellent experience in using them to access electronic library resources. The 2013 survey results indicated that universities were not investing wireless network infrastructure that will make it easier for students to use their own laptops and smartphones to access learning materials. There was however no research on the universities readiness for m-learning from the 2013 e-readiness survey. This is an indicator that there is need to conduct research in mobile learning in order to determine the degree of preparedness of Kenyan universities in embracing this new technology.

\subsection{RESEARCH PROBLEM}

Despite these meaningful efforts, the use of mobile devices as teaching and learning tools have not been given much attention at all levels of learning-institutions of higher learning inclusive. This is despite the fact that there is wide use of mobile devices by a majority of students in these institutions of higher learning. The e-readiness survey of East African universities (2008) shows that on average, all universities in the region were in stage two of the four-stage Harvard index in three indicators that included internet affordability, internet availability and network speed.

According to Graham, Adams \& Kahiro (2012), there should be clear guidance in the adoption of m-learning technologies in learning institutions. However, literature review reveals that a framework is lacking in Kenyan Universities and this 
makes the m-learning adoption process difficult yet majority of University students own mobile phones (Graham, Adams \& Kahiro, 2012).

The lack of a mobile learning model is the main reason why it is necessary to have a study that will investigate the university readiness towards the use of mobile devices for learning and design a readiness model for its adoption.

This study endeavored to answer the following research questions:

1. What technological factors influence mobile learning readiness in Kenyan universities?

2. How are learners and lecturers prepared for m-learning in Kenyan universities?

3. What is the appropriate m-learning readiness model for Kenyan Universities?

To answer these questions, the researcher conducted a study in Maseno University in Kenya guided by the following objectives:

1. To determine the technological factors that influence mobile learning readiness.

2. To establish learners' readiness on mobile learning in Kenyan Universities.

To develop a model for m-learning readiness assessment in Kenyan Universities

Data collection instrument was tested using Cronbach's Alpha coefficient, which is a scientific measure that determines the extent to which all items in a test measure the same concept or construct. The data collected was analyzed scientifically using SPSS program, version 20. Regression analysis was performed to determine the relationship between various factors in which positive coefficient indicates a positive relationship between the factors while a negative $\beta$ coefficient means that there is a negative relationship while 0 (zero) $\beta$ coefficient denotes no relationship between the variables. This research paper is organized as follows. Section two deals with literature review, section 3 presents the methodology, section 4 presents the results analysis and section five gives the conclusion of the study.

\subsection{LITERATURE REVIEW}

This chapter was presented according to the Research Objectives. It comprises of literature review organized in the following subsections: to determine the technological factors that influence mobile learning readiness in Universities, establish lecturers' and learners' readiness towards mobile learning and analysis of m-learning readiness models adoption in higher institutions of learning.

\subsection{Lecturers' and learners' readiness on mobile learning}

When new technology is born, it is important to find out if lecturers' and students' are ready to accept the technology. If mobile learning is to be integrated in Kenyan universities, then readiness of teachers and students should be determined. According to Ahonen (2007), there exist around 2.7 billion active mobile phones worldwide. This demonstrates the huge opportunity that mobile learning presents to students and instructors (Aker, Ksoll \& Lybbert, 2012). Successful integration of $\mathrm{m}$-learning in higher learning institutions cannot be achieved without assessing lecturers and learners readiness of such technologies.

In their study, Luoto \& Levine (2014) noted that there is need to determine teacher's perception in m-learning. However, there is the need to observe that learners are equally critical in the learning equation and therefore their perceptions towards m-learning are equally important. Kim, Kim, Buckner, Kim, Makany, Taleja, \& Parikh (2012) found that it is possible to widen the learning environment beyond classroom walls and school programs by using mobile devices. Gruman (2010) described mobile learning as a learning model that allows learners to get learning content anywhere and anytime using mobile technologies and the internet. Carole (2008) noted that the major reason of not using technology at the expected level is the willingness of teachers in using the technology in their lessons and the difficulties they face in reaching the required resources.

Aggarwal (2013) observed that although there has been no widespread research on mobile learning, studies that have so far been done argue for its importance in knowledge acquisition. This clearly demonstrated that there was need to do research on mobile learning in Kenyan universities.

Learners can often take advantage of unexpected free time since they normally carry mobile phones wherever they go Mindila, Rodrigues, McCormick \& Mwangi (2014). In his study, Corbeil \& Valdes-Corbeil (2007) notes that frequent use of mobile devices does not mean that students or lecturers are ready for m-learning and teaching. This means that technology alone does nothing to enhance pedagogy and therefore lecturers must be trained in the use of tools, not just giving them access to the tools (Mutua, 2012). A pedagogical theory and framework are required for efficient use of technology in education. Issa \& Fields (2013) conducted a study to establish the behavioral intention of university students in Korea observed that a shift from e-learning to mobile learning as mobile technology becomes popular in both formal and informal education in Korea.

While e-learning focuses on the use of both wired and wireless internet, m-learning is based on opportunities offered by mobile technologies such as cell phones, smart-phones, palmtops, tablet personal computers, personal digital assistants and portable multimedia players Salim (2013). Pollara \& Broussard (2011) who observed that m-learning is a new and independent part of e-learning supported this observation. 
Beard, Greenfield, Morote \& Walter (2011) observed that some Universities in Korea provided students with smart phones for free and learning management systems for mobile learning. In Kenya however, there is no policy on mobile learning, despite the growth of the number of students owning mobile devices.

In his study on internet use among primary school teachers, [9] stated that most frequent users were computer and natural science teachers, followed by mathematics, social sciences and foreign languages teachers. Many researchers agree that teachers will be successful in integrating technology in education in their areas of specialization if they are trained on the use of technology in their subject (Keskin \& Metcalf, 2011).

A research conducted by (Medani, 2011) revealed that $(25.3 \%)$ of students who participated in the survey strongly agreed that mobile learning can be an effective method of learning. It also showed that $39.2 \%$ of students felt that mobile learning can be more a flexible method of learning because it can be done anywhere and at any time while (31.7\%) of the respondents strongly agreed that mobile learning can improve communication between students and teachers.

According to the studies in literature, gender is a significant factor in mobile use. Mutua (2012) indicated that male students sent more and longer messages in cyberspace Chang, Littman-Quinn, Ketshogileng, Chandra, Rijken, Ghose, \& Kovarik (2012), however, argued in their study that female students sent messages more frequently. Colaco, NabaliaMakhanu \& Salim (2012) argue that mobile phone use is gender neutral. The current study tried to determine if there was significant gender difference in the use of mobile devices.

Today's students of higher learning institutions are a product of immersion in the technological advances of the past two decades. These learners are referred as digital natives (Attewell, 2005). Corbeil \& Valdes-Corbeil (2007) observed that today's instructors, who are not familiar with digital language of their learners, must learn it to maximize learning and access to learning. A study conducted at the University of Scranton noted that students were willing to spend on internet connectivity in order to facilitate mobile learning.

\subsection{Learners' Readiness on Mobile Learning}

Modern day learning is anchored on the constructivist learning theory. Under this theory, the learner is allowed time to construct knowledge from the environment. One such an approach is the m-learning. M-learning can be an effective method of learning as it can give immediate support. M-learning will bring new opportunities of learning. M- Learning will be a more flexible method of learning since it can be used seamlessly without being limited to time and location.

Recent research conducted by Pollara \& Broussard (2011), which focused on summarizing student's perceptions on mobile learning, claimed that prior researchers originally suggested consideration of student perceptions of mobile learning as an area in the future research of mobile learning. This consideration of student perceptions is evident in the research.

Most of the studies show a positive outcome on students' perceptions about mobile learning in a total of 18 research studies (Clarke, Keing, Lam, \& McNaught, 2008); Al-Fahad (2009; Wang, Shen, Novak, \& Pan, 2009); (Garrett \& Jackson, 2 006); (Cavus \& Uzunboylu, 2009); Maniar, 2007) \& (Maag, 2006). Consistent with previous studies, learners suggested that mobile learning improved their learning experiences and made the learning process more interesting (Rogers, Connelly, Hazlewood \& Tedesco, 2010); (Venkatesh, 2000) \& (Wang, Shen, Novak \& Pan, 2009) cited . (Pollara \& Broussard, 2011). Although these studies were conducted in developed countries, there is a similarity in the way students perceive mobile learning in Kenya.

\subsection{Lecturers' Readiness on Mobile Learning}

Experience over the years has shown that teachers have been depending on excessive use of words to express, to convey ideas or facts in the teaching-learning process. This practice is termed the "chalk-talk" method. Today, advances in technology have made it possible to produce materials and devices that could be used to minimize the teachers talking and at the same time, make the message clearer, more interesting and easier for the learners to assimilate [34]. It is against this backdrop that $\mathrm{m}$-learning comes in handy.

\subsection{Internet Connectivity and Affordability}

Internet connectivity refers to the ability of a mobile device to access the World Wide Web while internet affordability is the ability of accessing internet at lower costs. A study commissioned by the Communications Authority of Kenya (2007) observed that provision of internet access is currently availed by a hierarchy of providers who buy bandwidth from the global internet backbone to internet service providers (ISPs) who in turn sell to end users. The cost at each level down the hierarchy is passed down to the final consumer. The cost is therefore increasing as you move down the hierarchy while quality is decreasing.

Mobile learning can be an effective method of learning as it can give immediate support to the conventional chalkboard and chalk learning. Mobile learning brings new opportunities of learning to the class Pollara \& Broussard (2011). Essentially, this makes the learning process more interesting due to its interactive nature between the learners and tools supporting the process as noted by (Jeong, 2007).

Despite the flexibility of mobile-learning technologies, numerous studies have shown that internet connectivity and affordability offers the greatest challenge to the achievement of learning objectives (Pollara, 2011). According to a study carried out on internet affordability at Harvard, internet affordability was at stage 1.5 of the Harvard index scale. This means that Universities were spending about USD 13,000 per 1000 students that represent less than $1 \%$ of their annual 
budget according to the e-readiness survey of East African Universities (2014/2015). Therefore, the study intended to find out internet accessibility to learning institutions as a way of anchoring $m$-learning in institutions of higher learning.

\subsection{Institutional Strategy}

To Institutionalize m-learning, a policy needed to be put in place to offer the scope and depth of entrenching the concept in the teaching and learning process. A policy is a statement of commitment by an organization that stipulates how certain specific programs of action directed at achievement of specific goals in the organization should be arrived at. It is a principle of action adapted or proposed by a government or organization.

According to Sameer Hasan Al-Bakri (2011), a policy is a statement by the government to provide a uniform plan of action. It is developed to influence or shape the way people behave. Policy in education is important because it sets up rationale basis for decision making about resources allocation and use. It also calls for the government to account for the tasks.

When new technology is integrated in the curriculum, there should be a properly formulated policy that should direct the integration of the technology in the program so that its impact to the curriculum implementation process is felt positively. In this respect, a policy analysis is supposed to be conducted to establish the status of technology integration. Komunte \& Rwashana (2012 views a policy analysis as development of knowledge about policy process itself and improvement of information available to policy makers.

\subsection{M-learning Readiness Assessment Models}

Literature on higher learning institutions' readiness for m-learning provides guidelines to educators and policy makers on the appropriate approaches for assessing m-learning readiness in learning institutions. M-learning can be evaluated by assessing students and lecturers' technical experience and competency in the use of mobile phones in teaching and learning. Various researchers have developed considerable number of $\mathrm{m}$-learning models. The models analyzed below had fundamental factors that were helpful in conducting this research.

\subsection{M-learning Readiness Model}

Nada, Lonsdale, Vavoula \& Sharples (2013) developed a model to be used in measuring m-learning readiness of higher learning institutions in Saudi Arabia. The model looked at perceived ease of use and perceived usefulness as key predictors of assessing lecturers' readiness for mobile learning in higher education. The hypothesized mobile learning readiness model exhibited that lecturers were ready to use m-learning in terms of usefulness and ease of use for their teaching and learning in Saudi Arabian higher education. These findings are consistent with the findings of the study conducted by Venkatesh (2000) which showed that perceived usefulness and perceived ease of use were significant predictors of m-learning readiness.

Some researchers think that technology acceptance is more complex than previously thought and have considered other key variables that promote acceptance (Taylor \& Todd, 1995). According to Thompson, Compeau \& Higgins (2006), TAM has two prominent themes, which are instrumental determinants. The slimness of the model is also measured as a fundamental restriction, while ungenerousness of TAM makes it limited to relate to a variety of conditions Shen, Hiltz \& Bieber (2009). Thompson, Compeau \& Higgins (2006) argued that although these major premises have provided the technology acceptance stream well, perceived ease of use and perceived usefulness are not the only valid determinants related to technology adoption, especially with regard to newer technologies.

\subsection{A Mobile Learning Readiness Model for Distance Education Students}

Tagoe \& Abakah (2014) designed a model to assess the readiness of distance education learners in Ghana to adopt mobile learning. The study used the Theory of Planned Behavior (TPB) to explain how students' beliefs affected learners' intention to adopt m-learning. Findings from the study showed that majority of the learners owned mobile phones, and used them for conversation and sending text messages. Majority of younger learners tended to own smart phones when compared to their older colleagues. Factor analysis that was conducted gave strong loadings of factors such as intentions and perceived behavioral control there by confirming that TPB explained the students' m-learning readiness quite well. Attitude, subjective norm and behavioral control influenced students' intention in adopting m-learning.

\subsection{Mobile Learning in Higher Education: Students' Acceptance of Mobile Learning}

Zaka (2009) developed a mobile readiness model to be used in assessing mobile learning readiness in three top Chinese Universities. The model identified nine key constructs for measuring readiness based on perception. They include; perceived mobility, perceived enjoyment, perceived usefulness, perceived ease of use, attitude, and behavior intention, perceived output quality, prior experience and perceived social interaction. The model was biased on perception, leaving other key constructs such as technological factors, which are crucial to mobile learning.

\subsection{RESEARCH METHODOLOGY}

\subsection{Research Design}

The study utilized a case study approach to establish information about the status or level of m-learning infusion in learning programs in Maseno University. The research design was guided and structured by the research 'onion' that was 
developed by Saunders, Lewis \& Thornhill (2007). In respect to this, the research methodology part of this thesis was classified into five sub-topics that endeavored to give a detailed justification of the research process.

\section{2. $\quad$ Date Collection}

Questionnaires were developed and used to collect data from respondents in the two different users of mobile learning devices in the universities. Two sets of questionnaires were used to target lecturers and students. The researcher used closed-ended questions when developing the questionnaires. The respondents were selected from departmental heads of the university, students and lecturers of Maseno University.

\subsection{Sampling}

The sample population was stratified into two groups namely university learners and lecturers. Stratified sampling technique was used to help obtain a sample size that is as heterogeneous as possible. A scientifically tested approach was used to target a group of respondents that would give a reliable feedback. The data collected was analyzed scientifically using SPSS program, version 20.

\subsection{Research Approach}

The study adopted inductive research approach. Inductive approach was employed because the study was geared towards establishing a model for m-learning after gathering for relevant data to come up with patterns that will enable the construction of the model.

The study employed exploratory research process. This was suitable because it aimed to reveal new insight and evaluate the research phenomena in a new light. This research approach was also flexible to establish its theoretical propositions (Maxwell, 2012).

\subsection{Data Analysis}

Data collected was summarized, organized and analyzed using descriptive and interpretive analysis method to help answer the research questions. The collected data was analyzed using SPSS software after coding.

\subsection{DISCUSSION OF RESULTS}

The F-ratio in the ANOVA table tests whether the overall regression model is a good fit for the data. The table shows that the independent variables statistically significantly predicts the dependent variable, $F(4,25)=7.183, P<.05$ (i.e the regression model is a good fit of the data) thus the model, is statistically significant in predicting the mobile learning readiness of both lecturers and learners in Kenyan Universities.

\section{Table: 5.1 Regression Analysis}

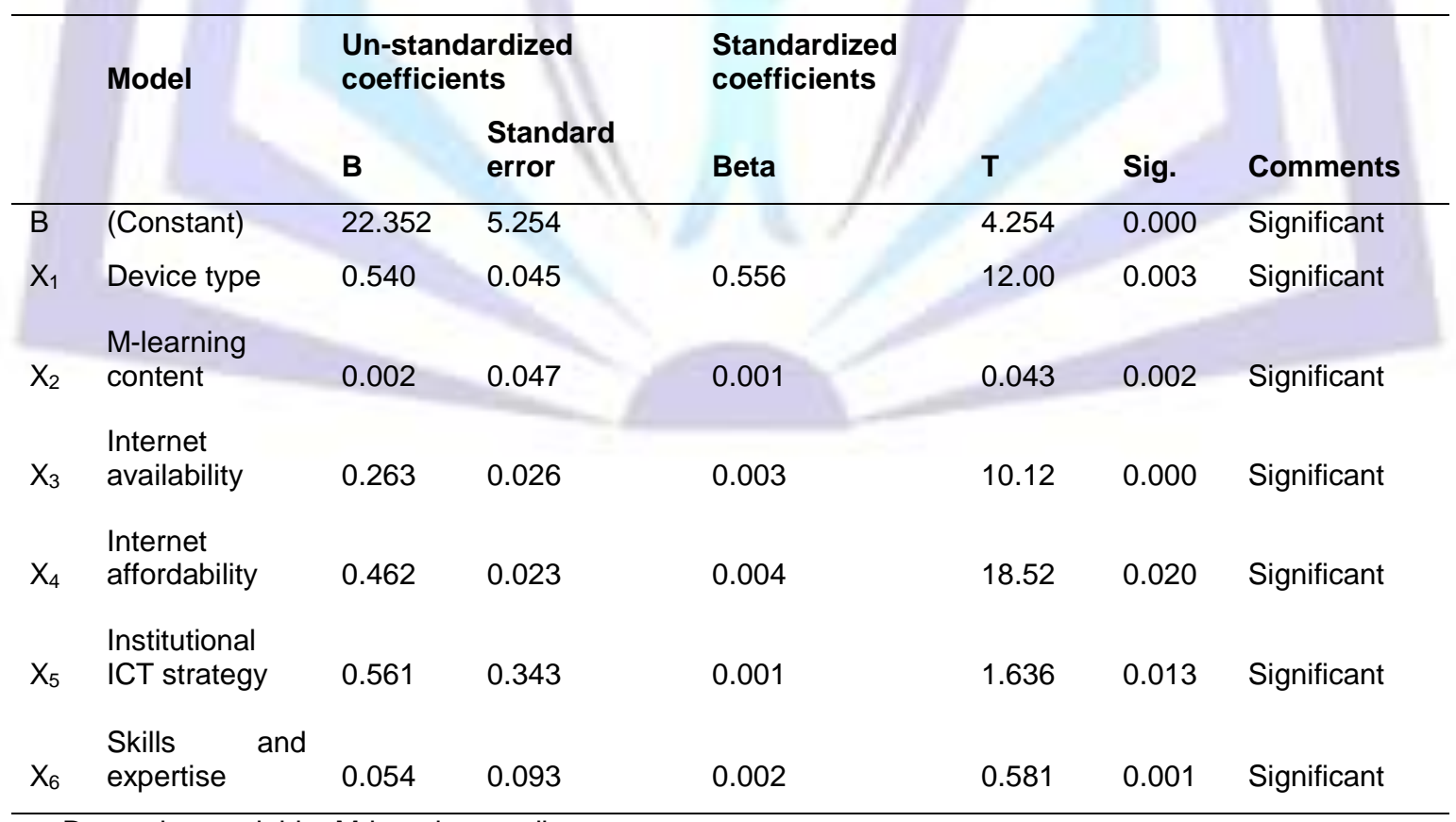

a. Dependent variable: M-learning readiness

As per the SPSS generated table above, the regression equation becomes

$Y=22.352+0.540 x_{1}+0.002 x_{2}+0.0263 x_{3}+0.462 x_{4}+0.561 x_{5}+0.054 x_{6}+u$ 
In the results of the table above, the $B$ coefficients (the plus or minus sign) interpreted the direction of the relationship between variables. When a $B$ coefficient is positive, then the relationship of this variable with the dependent variable is positive and if the $B$ coefficient is negative then the relationship is negative, if the $\beta$ coefficient is equal to 0 (zero), then there is no relationship between the variables. Beta value is used to assess the strength of the relationship between each independent variable to the dependent variable and the higher the beta value the greater the impact of the independent variable on the dependent variable.

A multiple linear regression model indicates that the six independent variables have positive $B$ coefficients. According to the regression model equation established, device type, m-learning content, internet availability, internet affordability, institutional ICT strategy and skills and expertise at a constant of Zero, the mobile learning will be 22.352 . At $5 \%$ level of significance and 95\% level of confidence, Device type had a 0.003 level of significance, m-learning content had 0.002 level of significance, internet availability had 0.000 level of significance, internet affordability had 0.020 level of significance, Institutional ICT strategy had 0.000 and skills and expertise had 0.013 level of significance.

Data collected was analyzed under the hypothesis "there is no relationship between learners and lecturers perception and mobile learning readiness in Kenyan universities".

This study used the Chronbach's alpha to evaluate the internal consistency reliability. All measures were expected to have higher reliabilities than 0.70 (Maxwell, 2012). Coefficient alpha of 0.70 is considered adequate. All the constructs of the questionnaire exceeded 0.70 in Chronbach's alpha value.

The results obtained after analyzing the lecturers' responses on perception on mobile learning also indicated that they too had a positive perception towards mobile learning. Most of them agreed that mobile learning is a better means of acquiring knowledge, that mobile learning saves time, that mobile learning is cost effective and other variables that measured perception indicated a positive response. The results on the perception of both learners and lecturers were further analyzed using simple regression model to establish the level of significance of the relationship between the constructs and the dependant variable, which is mobile learning readiness.

Table 5.2: Summary of regression analysis.

\section{Coefficients}

\begin{tabular}{llllllll}
\hline \multicolumn{7}{c}{ Model } & \multicolumn{2}{l}{$\begin{array}{l}\text { Unstandardized } \\
\text { Coefficients } \\
\text { B }\end{array}$} & Std. Error & $\begin{array}{l}\text { Standardized } \\
\text { Coefficients }\end{array}$ & & & \\
& & Beta & t & Sig. & Comments \\
\hline$B$ & (constant) & 2.015 & 0.746 & & 5.321 & 0.000 & Significant \\
$\mathrm{P}_{1}$ & $\mathrm{PU}$ & 0.263 & 0.026 & 0.003 & 4.031 & 0.000 & Significant \\
$\mathrm{P}_{2}$ & PEOU & 0.054 & 0.093 & 0.002 & 5.239 & 0.001 & Significant \\
$\mathrm{P}_{3}$ & POQ & 0.001 & 0.118 & 0.015 & 0.009 & 0.521 & Not significant \\
$\mathrm{P}_{4}$ & ATT & 0.167 & 0.052 & 0.001 & 5.231 & 0.002 & Significant \\
$\mathrm{P}_{5}$ & PMV & -0.834 & 0.112 & 0.003 & 0.032 & 0.642 & Not significant \\
$\mathrm{P}_{6}$ & PE & 0.004 & 0.345 & -0.052 & 0.008 & 0.743 & Not significant \\
\hline
\end{tabular}

a. Dependent Variable: M-learning readiness

As per the SPSS generated table above, the regression equation becomes

$\mathrm{Y}=2.015+0.263 \mathrm{P}_{1}+0.054 \mathrm{P}_{2}+0.001 \mathrm{P}_{3}+0.167 \mathrm{P}_{4}-0.834 \mathrm{P}_{5}+0.004 \mathrm{P}_{6}+\mathrm{u}$

Key:

PU- Perceived usefulness

PEOU- Perceived Ease of Use

POQ- Perceived Output Quality

ATT- Attitude

PMV- Perceived Mobility Value

PE- Perceived Enjoyment.

The above multiple linear regression model indicates the six sub independent variables from the independent variable perception have positive $\beta$ coefficients while only one has a negative $\beta$ coefficient. Consistent with previous research, in the field of information technology, perceived usefulness, perceived ease of use and attitudes have a significant positive 
influence on learners and lecturers' readiness towards mobile learning are. However, Perceived Output Value, Perceived Mobility Value and Perceived Enjoyment had no any significance in the mobile learning Readiness for both learners and Lectures.

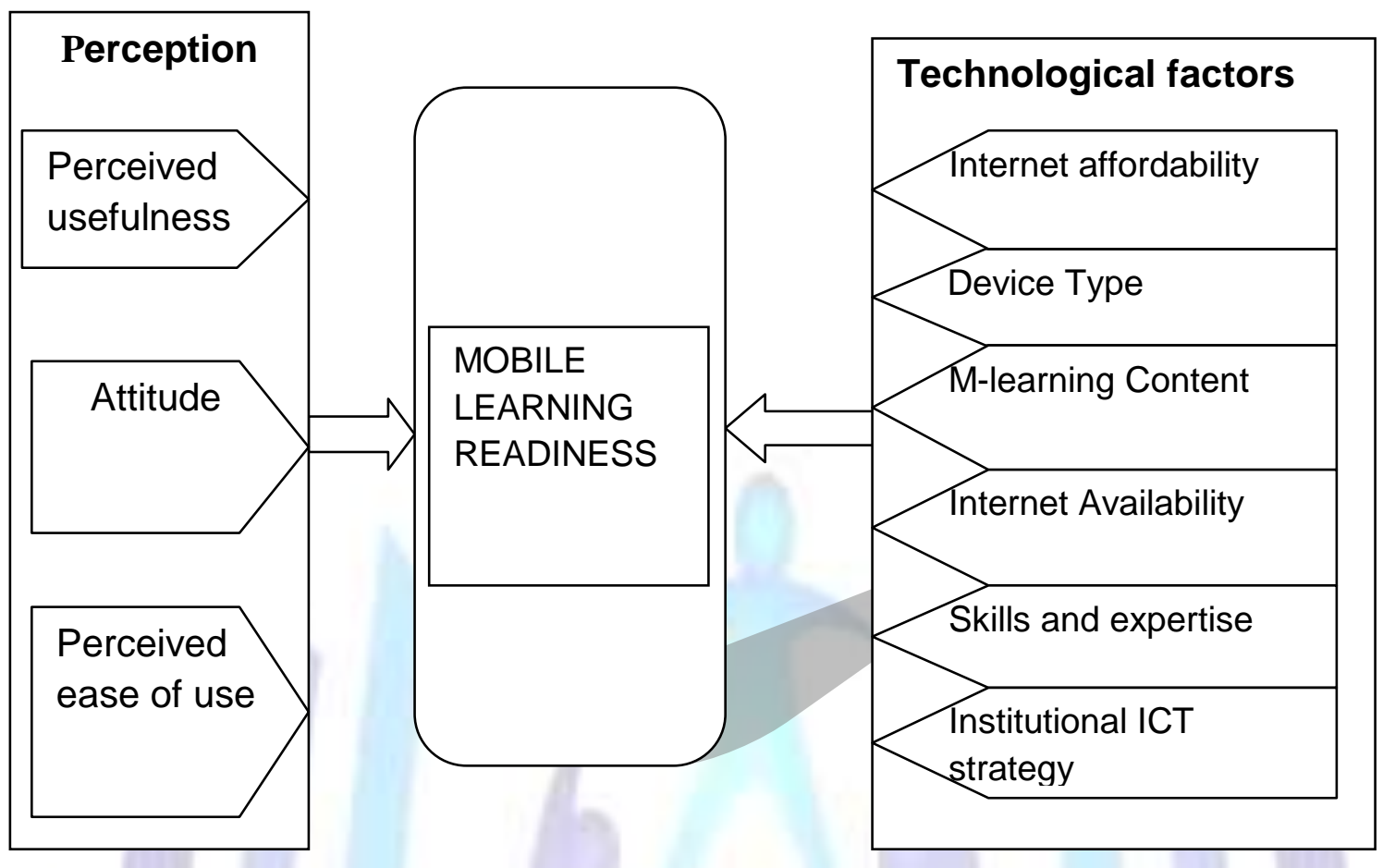

Fig 5.1: Proposed mobile learning readiness model showing factors that affect mobile learning readiness in

\subsection{CONCLUSION} Kenyan universities

Gaining a deeper understanding of the factors that influence the adoption of mobile learning devices in universities provides a good basis for mobile learning readiness among university lecturers and students. The study reveals that understanding these factors is critical to help develop a model of adopting m-learning approach. The study endeavored to determine the factors that influence the learning readiness in Kenyan universities and the appropriate $\mathrm{m}$-learning readiness model for Kenyan universities. The regression analysis and results shows that device type, m-learning content, internet affordability, institutional ICT strategy, skills and expertise, were critical factors that affect m-learning readiness among university students. A model was developed for assessing the mobile learning readiness. Regarding readiness of learners and lecturers, the factors identified in the model explained $74.6 \%$. These factors included perceived ease of use, perceived usefulness and attitude. The model therefore is ideal for measuring mobile learning readiness in Kenyan Universities.

In conclusion, the results of the study indicate that universities need to develop strategic plans and guidelines to support students' readiness by focusing on critical factors for development of a viable m-learning model. The results of this study can be used to help policy developers to gain insight into essential factors that can be taken into account when designing an m-learning system in Kenyan universities.

\section{ACKNOWLEDGEMENTS}

I would like to thank all the students and lecturers for their willingness to participate in this study.

\section{REFERENCES}

1.Medani, A. G. (2011). Review of mobile short message service security issues and techniques towards the solution. Scientific Research and Essays, 6, 1147-1165.

2. Winters, N. (2013). Mobile learning in the majority world: A critique of the GSMA position. The SAGE Handbook of Digital Technology Research, 402.

3. Georgiev, T., Geirgieva, E., \& Smrikarov, A. (2004). M-learning - A new stage of e-learning. Re-trieved December 4, 2011, from http://ecet.ecs.ru.acad.bg/cst04/Docs/sIV/428.pdf

4. Ratemo, J. (2012). Rogue Technicians Keep CCK awake after Banning Fakes.

5. Habitzel, J. (2006). Satisfaction with internet-based services. Paper presented at the $35^{\text {th }}$ Hawaii International Conference on System Sciences. Big Island, Hawaii. 
6. Salim, A. (2013). Growth of mobile education platforms and the impact on learning in primary schools in Kenya. Edulearn13 Proceedings, 2450-2455.

7. Ogechi, N. O., \& Bosire-Ogechi, E. (2011). Identity and the New Communication Technologies: Evidence from Kenya. Cultural Identity and New Communication Technologies: Political, Ethnic and Ideological Implications, 23.

8. Graham, M. D., Adams, W. M., \& Kahiro, G. N. (2012). Mobile phone communication in effective human elephantconflict management in Laikipia County, Kenya. Oryx, 46(01), 137-144.

9. Ahonen, J. (2007). M-learning: Strategies for delivering Knowledge in the digital age. New York: McGraw-Hill.

Green, S. B., \& Salkind, N. J. (2010). Using SPSS for Windows and Macintosh: An alyzing and understanding data. Prentice Hall Press.

10. Luoto, J., \& Levine, D. I. (2014). Mobile Phones, Rent-to-Own Payments \& Water Filters: Evidence from Kenya.

11. Kim, P., Buckner, E., Kim, H., Makany, T., Taleja, N., \& Parikh, V. (2012). A comparative analysis of a game-based mobile learning model in low-socioeconomic communities of India. International Journal of Educational Development, 32(2), 329-340.

12. Gruman, G. (2010). Mobile security definition and solutions. New York: Cengage Learning.

13. Carole, L (2008). Am J health-syst pharm journal - vol 65 Dec 1, 2008, 1-152

14. Aggarwal, A. (2013). Higher Education Collaboration in Kenya: Challenges and Perspectives. International Journal of Technology and Educational Marketing (IJTEM), 3(1), 48-64.

15. Mindila, A., Rodrigues, A., McCormick, D., \& Mwangi, R. (2014). An Adaptive ICT-Enabled Model for Knowledge Identification and Management for Enterprise Development. International Journal of System Dynamics Applications (IJSDA), 3(1), 71-89.

16. Corbeil, J. R., \& Valdes-Corbeil, M. E. (2007). Are you ready for mobile learning?. Educause Quarterly, 30(2), 51.

17. Mutua, J. N. (2012). A framework for evaluating mobile learning (M-learning) systems in Kenya (Doctoral dissertation, University of Nairobi, Kenya).

18. Issa, N., \& Fields, S. (2013). A Mobile-Based E-Learning System. European Journal of Applied Engineering, 11(2), 2538.

19. Beard, K. V., Greenfield, S., Morote, E. S., \& Walter, R. (2011). Mobile technology: lessons learned along the way. Nurse educator, 36(3), 103-106.

20. Keskin, N. O., \& Metcalf, D. (2011). The Current Perspectives, Theories and Practices of Mobile Learning. Turkish Online Journal of Educational Technology-TOJET, 10(2), 202-208.

21. Chang, A. Y., Littman-Quinn, R., Ketshogileng, D., Chandra, A., Rijken, T., Ghose, S. \& Kovarik, C. L. (2012). Smartphone-based mobile learning with physician trainees in Botswana. International Journal of Mobile and Blended Learning (IJMBL), 4(2), 1-14.Cheltenham: Nelson Thornes Ltd.

22. Colaco, J., Nabalia-Makhanu, E., \& Salim, A. (2012). Development of local educational digital content for schools in Kenya using the mobile device as an acceleration tool to enhance learning and facilitate collaborative learning. iceri2012 Proceedings, 1856-1861.

23. Attewell, K. (2005). From research and development to mobile learning. Tools for education and training providers and their learners. Retrieved on 23 April 2014, from http://www.mlearn.org.za

24. Clarke, P., Keing, C., Lam, P., \& McNaught, C. (2008). Using SMSs to Engage Students in Language Learning. Proceedings of World Conference on Educational Multimedia, Hypermedia and Telecommunication. Chesapeake, VA: AACE. 6132-6141.

25. Al-Fahad, F. N. (2009). Students' Attitudes and Perceptions towards the Effectiveness of

26. Wang, M., Shen, R., Novak, D., \& Pan, X. (2009). The Impact of Mobile Learning on Stu-dents' Learning Behaviours and Performance: Report from a Large Blended Class-room. British Journal of Educational Technology, 40(4), 673-695.

27. Garrett, B. M., \& Jackson, C. (2006). A mobile clinical e-portfolio for nursing and medical students, using wireless personal digital assistants (PDAs). Nurse Education Today, 26(8), 647-654

28. Cavus, N., \& Uzunboylu, H. (2009). Improving critical thinking skills in mobile learning.

29. Maniar, N. (2007). M-learning to teach university students. In C. Montgomerie \& J. Seale (Eds.). Proceedings of World Conference on Educational Multimedia, hypermedia

30. Maag, M. (2006). iPod, uPod? An emerging mobile learning tool in nursing education and students' satisfaction. In Who's learning? Whose technology? Proceedings

31. Rogers, Y., Connelly, K., Hazlewood, W. R., \& Tedesco, L. (2010). Enhancing learning: a study of how mobile devices can facilitate sense making. Personal \& Ubiquitous Computing, 14(2), 111-124. 
32. Venkatesh, V. (2000). Determinants of perceived ease of use: Integrating control, intrinsic motivation, and emotion into the technology acceptance model. Information Systems Research, 11(4), 342-365.

33. Pollara, P. \& Broussard, K. K. (2011). Student Perceptions of Mobile Learning: A Review of Current Research. Society for Information Technology \& Teacher Education International Conference.

34. Aker, J. C., Ksoll, C., \& Lybbert, T. J. (2012). Can mobile phones improve learning? Evidence from a field experiment in Niger. American Economic Journal: Applied Economics, 4(4), 94-120.

35. Jeong, (2007). Effective M-learning Design. MERLOT Journal of Online Learning and Teaching, 4(4).

36. Sameer Hasan Al-Bakri, M. L. (2011). Securing peer-to-peer mobile communications using public key cryptography: New security strategy. International Journal of the Physical Sciences, 6, 930-938.

37. Nada, L., Lonsdale, P., Vavoula, G., \& Sharples, M. (2013). Mobile technologies and learning. Retrieved from http:// archive.futurelab.org.uk/resourses/publications-reports-articles/literature-reviews/literature-review203

38. Tagoe, M., \& Abakah, E. (2014). Determining distance education students' readiness for mobile learning at University of Ghana using the Theory of Planned Behavior. International Journal of Education and Development using Information and Communication Technology, 10(1), 91.

39. Zaka, U. (2009). An instructional model for web-based M-learning education with a blended learning process approach. British Educational Communications and technology, 34(3)

40. Komunte, M., \& Rwashana, A. S. (2012). Comparative analysis of mobile phone usage among women entrepreneurs in Uganda and Kenya. www. ajocict. net, 5(5), 63.

41. Taylor, S., \& Todd, P. (1995). Understanding information technology usage: A test of competing models. Information Systems Research, 6(2), 144-176.

42. Thompson, R., Compeau, R.D., \& Higgins, C. (2006). Intentions to use information technologies: an integrative model. Journal of organizational and End User Computing, 18(3), 25-47

43. Shen, J., Hiltz, S. R., \& Bieber, M. (2009). Intentions to use virtual worlds for education. Journal of information systems education, 20(2), 225-233

44. Saunders, M. Ph Lewis, \& A. Thornhill, (2007). Research methods for business students, $4^{\text {th }}$ edition, Prentice Hall.

45. Maxwell, J. A. (2012). Qualitative Research Design: An Interactive Approach: An Interactive Approach. Sage.

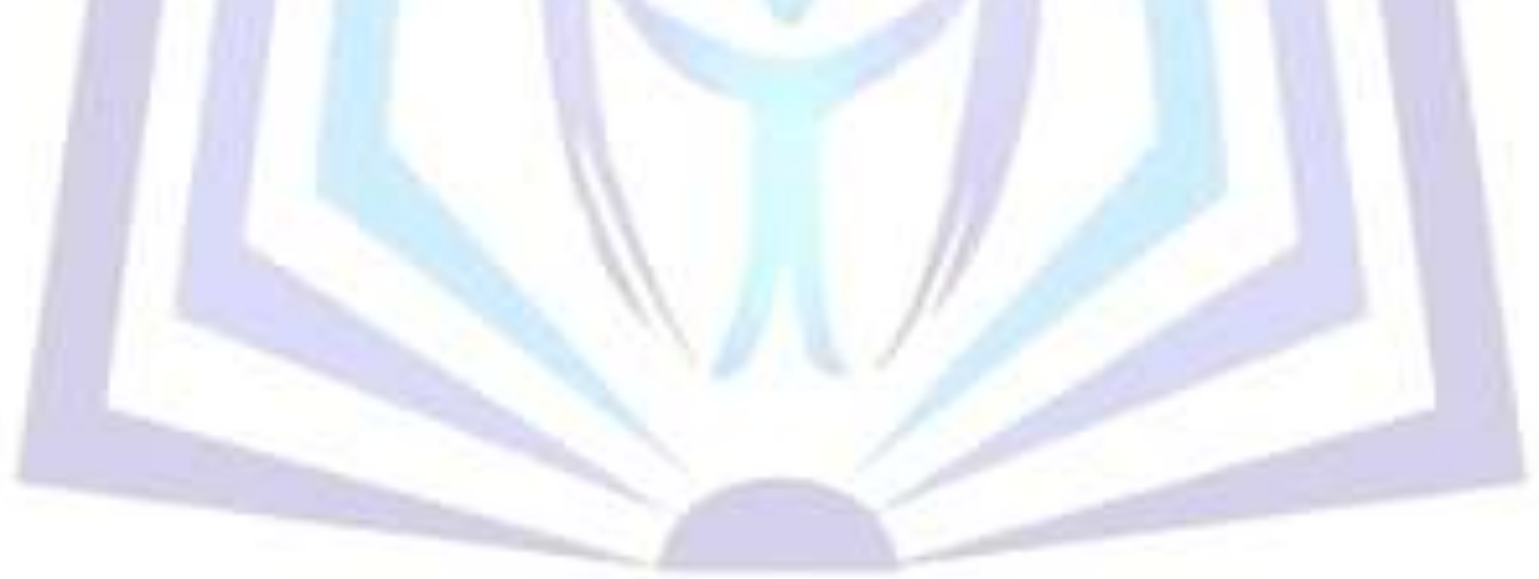

